\title{
ПІСЛЯДИПЛОМНА МЕДИЧНА ОСВІТА - НОВІ ГОРИЗОНТИ Й ПЕРСПЕКТИВИ
}

\author{
Ю. В. Вороненко, О. П. Мінцер, О. В. Палагін ${ }^{1}$ \\ Національна медична академія післядипломної освіти імені П. Л. Шупика, \\ ${ }^{1}$ Інститут кібернетики імені В. М. Глушкова НАН Украйни
}

\section{POST-GRADUATE MEDICAL EDUCATION - NEW HORIZONS AND PERSPECTIVES}

\author{
Yu. V. Voronenko, O. P. Mintser, O. V. Palahin ${ }^{1}$ \\ P. Shupyk National Medical Academy of Post-Graduate Education, \\ ${ }^{1} V$. Hlushkov Institute of Cybernetics of NAS of Ukraine
}

\begin{abstract}
Представлено нове розуміння проблем передавання знань, змісту освіти та управління нею. На часі поставлено питання післядипломного додаткового проблемно-орієнтованого навчання, особливо в медицині, що включає такі нові напрями, як полідисциплінарність, мультидисциплінарність та трансдисциплінарність. Виникає необхідність створення єдиного банку контрольно-вимірювальних методик для перевірки залишкових знань не тільки з дисциплін, а й 3 навчальних модулів. Не менш важливим стає й введення так званої “нелінійної” схеми організації навчального процесу.

Розроблення суворої методології трансдисциплінарності наукових досліджень та освіти виявило особливу роль інформатики як елемента їі системно-технологічної підтримки, враховуючи системоутворюючу роль сучасної інформатики та інтеграцію інформаційних технологій практично в усі галузі науки й освіти.

Запропоновано розділити навчання лікарів і провізорів у стратегії безперервного професійного розвитку в післядипломній медичній освіті на дві частини - базисну та додаткову (трансдицисплінарну, проблемно-орієнтовану) з заданим рівнем компетентності.
\end{abstract}

The article presented a new understanding of knowledge transfer, the contents and management of education. It was established the question of additional post-graduate problem-oriented education, especially in medicine, including such new educational techniques as a multidisciplinary, interdisciplinary and transdisciplinary. There is a need to create a single bank for control and measurement techniques to verify the residual knowledge not only by the disciplines but also by the training modules. No less important is the initiation of the so-called "non-linear" circuit of the educational process.

Developing rigorous methodology of transdisciplinary research and education identified the specific role of computer science as an element of its system-technological support, given the backbone role of modern science and the integration of information technologies in virtually all branches of science and education.

It was proposed to divide the training of doctors and pharmacists in continuing professional development strategy in postgraduate medical education in two parts - basic and additional (transdisciplinar, problem-oriented) with a specified level of competence.

Вступ. Інтеграційні процеси, що спостерігаються в усьому світі, обумовлені соціальним замовленням суспільства, виконання якого визначить дієздатність і конкурентоспроможність кожної національної освітньої системи, кожного університету, кожного викладача.

Водночас сучасні уявлення про методи передавання знань, взагалі у вищій освіті й у медичній освіті особливо, потребують їх якнайскоріших змін. Дійсно, у світі існує понад 8000 академічних дисциплін, понад 6000 мов. Відповідно практично неможливо домогтися адекватного розуміння наукових і прагматичних проблем, а також гармо-

(C) Ю. В. Вороненко, О. П. Мінцер, О. В. Палагін нізації освіти в різних країнах. Украй необхідне нове розуміння проблем передавання знань, змісту освіти та управління нею. Усвідомлення необхідності змінення логіки функціонування систем освіти зумовило ініціативу ряду країн у пошуку нових механізмів забезпечення привабливості та конкурентоспроможності національних систем освіти.

Реалії сьогодення потребують впровадження принципово нових підходів також до післядипломного навчання, в першу чергу, в медицині.

На часі поставлені питання післядипломного додаткового проблемно-орієнтованого навчання, що включають такі нові напрями, як полідисциплінарність, мультидисциплінарність та трансдис- 
циплінарність. Саме вони мають забезпечити створення гнучкої і мобільної системи додаткової освіти, спрямованої як на задоволення запитів конкретної особистості, галузі, регіону, так і інтеграції перспективних напрямів розвитку народного господарства. Зрозуміло, необхідна також апробація нових технологій, створених на базі інформаційних технологій, що діагностують отримані знання. Для цього необхідне створення єдиного банку контрольно-вимірювальних методик для перевірки залишкових знань не тільки з дисциплін, а й $з$ навчальних модулів. Не менш важливим стає й введення так званої “нелінійної” схеми організації навчального процесу.

Мета роботи - формалізація сучасних напрямів інтеграції знань та освіти.

Основна частина. Введемо визначення. Будемо розуміти під полідисциплінарністю навчальну технологію вивчення феномену (явища) одночасно з різних сторін декількома науковими дисциплінами у форматі відсутності такої характеристики, як інтегративність. Кожна дисципліна зберігає власну методологію.

Міждисциплінарність інтегрує різні методології та практики [1]. Вона досить часто вживається як синтез теоретичних знань, умінь, технологій. Усі вони будуються на певних когнітивних стратегіях. Отже, епістемологічний контекст міждисциплінарних досліджень $є$ невід'ємною їх компонентою. Саме в цьому сенсі міждисциплінарними є сучасні біотехнології та нанотехнології.

Розвиток науки в XX сторіччі носив явно міждисциплінарний характер, що зумовило необхідність розроблення методології міждисциплінарних наукових досліджень, включаючи нові перспективні архітектури інтелектуальних комп'ютерних систем. Очевидно, що міждисциплінарна парадигма передбачала побудову єдиної (уніфікованої) міждисциплінарної системи знань, що забезпечувала формалізовану постановку та вирішення конкретних завдань при виконанні перспективних наукових досліджень. Зрозуміло, що одним із головних завдань міждисциплінарних досліджень $є$ забезпечення ефективної міждисциплінарної взаємодії на всіх етапах життєвого циклу вирішення фундаментальних і прикладних наукових проблем [5].

Важливо підкреслити, що після етапу міждисциплінарних досліджень очікувалася поява більш високого етапу - трансдисциплінарності, що не обмежувався б суто міждисциплінарними відносинами, а розмістив би ці відносини всередині глобальної системи, без суворих кордонів між дисциплінами (Ж. Піаже, 1948). Отже, трансдисциплінарність можна уявити як новий простір знань, що $є$, по-суті, гіпердисципліною. Подібна трансдисциплінарність повинна бути “координатором усіх дисциплінарних i інтердисциплінарних систем навчання та інновацій на основі загального аксіоматичного підходу” (Еріх Янч, 16).

Численні публікації останніх років у даній області в більшості своїй присвячено суто філософським проблемам трансдисциплінарних досліджень, їх феноменологічної сутності, понятійним аспектам [6-8]. Підкреслюється, що поява зазначенних напрямів продиктована самим життям. Сьогоднішня наука далеко не завжди в змозі вирішити складні міждисциплінарні проблеми внаслідок роз'єднаності наукових дисциплін і їх спеціалізації, слабкої координації наукових колективів і їх тематики, відсутності системного моніторингу та загальної формалізованої мови представлення знань. Трансдисциплінарність як поняття апелює до загальної наукової картини світу, що відображає реальний світ у всьому його різноманітті та багатопов'язаних складових - просторових, часових, інформаційних і когнітивних [3].

Таким чином, перехід від міждисциплінарності до трансдисциплінарності - це перехід від паралельного аналізу до конструктивного діалогу та реалізації спільних проектів.

Раніше $[1,2]$ було запропоновано розглядати міждисциплінарність (так само, як і трансдисциплінарність) як окремий розділ інформатики, маючи на увазі її системоутворюючу функцію. В цьому випадку сутність подібних підходів до дослідження комплексних науково-технічних проблем полягає в ефективному забезпеченні двоєдності концепцій поглиблення конкретних знань у предметній області (ПрО), з одного боку, та розширення охоплення проблеми, виходячи з реальності єдності світу, з іншого. Підкреслюється, що йдеться про появу нових відносин між поняттями вихідних наукових дисциплін, встановлення нової системи законів, які їх пов'язують, вирішення завдань системної інтеграції при виконанні все більш складних завдань. При цьому знання вихідних дисциплін можуть залишатися незмінними, в найпростішому випадку включеними цілком або частково в нову ієрархічну систему знань, або ж зазнати модифікації завдяки процесам обміну парадигмальними положеннями, поняттями та методами різних наук (нелінійний випадок). Нелінійна міждисциплінарна взаємодія - норма еволюції су- 
часної науки. Процес, що багато разів повторюється: від однієї або групи дисциплін, через міждисциплінарну взаємодію в напрямі, що наближає створення цілісної загальнонаукової картини світу [19].

Розроблення суворої методології трансдисциплінарності наукових досліджень та освіти виявила особливу роль інформатики як елемента її системно-технологічної підтримки. Такий висновок абсолютно закономірний, враховуючи системоутворюючу роль сучасної інформатики та інтеграцію інформаційних технологій практично в усі галузі науки й освіти. Більш того, наука виявляється “інформаційно навантаженою” й перетворюється поступово в e-science. В освіті також відбуваються важливі зміни: широке впровадження віртуальної освіти (е-learning), систем автоматичного контролю знань, автоматичного виявлення здібностей тощо. Фантастичні масштаби експансії інформаційних технологій надають небачені раніше зрушення в соціальній сфері [21].

Однак слід зазначити нетривіальність і високу складність самого переходу від прямих методів наукових досліджень до досліджень на основі професійного управління знаннями (knowledge management) i, звичайно ж, засобів їх методологічної та інформаційно-технологічної підтримки [3]. Такими засобами можуть бути знання-орієнтовані інформаційні системи з онтолого-керованою архітектурою. Конструювання механізму, що лежить в основі методології наукових досліджень, безпосередньо пов'язано зі створенням концептуальнопонятійного каркаса відповідних наукових теорій, в якості якого може служити сукупність формальних комп’ютерних онтологій конкретних предметних областей досліджень.

Водночас констатується [12]: 1) сучасний розрив між зростаючою кількістю знань збільшує збідніння внутрішньої ідентичності, веде до народження нових форм обскурантизму з незліченними соціальними та особистісними наслідками;

2) наріжний камінь трансдисциплінарності семантичне та практичне об’єднання сенсів, що знаходяться за межами окремих дисциплін. Крайнощі формалізму, строгість визначень і докази абсолютної об’ єктивності, що тягнуть виключення суб'єкта, можуть мати тільки негативні наслідки;

3) трансдисциплінарність рішуче відкриває вихід за область точних наук, вимагаючи їх діалогу та їх примирення з гуманітарними та соціальними науками, а також із мистецтвом, літературою, поезією та духовним досвідом.
Шлях трансдисциплінарності пролягає через створення системології міждисциплінарної взаємодії як самостійного розділу інформатики, маючи на увазі вже згадану системоутворюючу її функцію, а також сукупність інформаційних технологій постановки та вирішення складних науково-технічних проблем.

Слід особливо зупинитися на ролі трансдисциплінарності в медичній освіті. Останній період розвитку медицини характеризуються надзвичайною інтеграцією досягнень низки напрямів науки. Окрім згаданих біотехнологій, нанотехнологій, різні дисциплінарні досягнення задіяні в таких напрямах, як променева діагностика, кардіологія, кардіохірургія, офтальмологія, реабіліталогія та десятках інших. Ці технології надзвичайно швидко змінюються. Тому саме завдання висвітлювати їх у базових медичних курсах нереальне. Більш того, сама суть передавання знань змінюється. 3’являються технології навчання дорослих, андрагогічні принципи освіти. Відповідно на етапах безперервного професійного розвитку повинні реалізовуватися багатоступенева післядипломна медична освіта з вираженими елементами проблемної орієнтації.

Отже, йде мова про створення принципово нової системи освіти, при якій передавання знань здійснюється декількома етапами, в першу чергу, шляхом передавання базисних знань, а також шляхом проблемно-орієнтованого навчання (в прямому розумінні цієї технології), для якого найважливішими характеристиками є трансдисциплінарність та створення необхідних компетенцій. Відповідно, обгрунтовується прогноз ефективності систем передавання знань, що, на думку експертів, визначає стратегію розвитку конкурентоспроможних університетів.

Головною та вирішальною визнається орієнтованість освітніх програм на ринок праці. Йдеться про рівень сприйнятливості вищої освіти до вимог економіки. У постіндустріальному світі освіта не тільки необхідна умова розвитку суспільства та кожної країни, вона стала потужною галуззю економіки, від успішного розвитку котрої багато залежить економіка в цілому i, зрозуміло, культура країни $[15,16]$. Не менш важливим є розвиток раціональної і плідної для ВНЗ і роботодавців систем взаємозв’язку.

Конкурентоспроможність ВНЗ визначається таким показником, як його готовність і здатність до “швидкої добудови спеціаліста”, створення умов для “самопроектування” фахівця відповідно до соціальних замовлень. 3 цієї точки зору виникає 
необхідність створення нового інформаційно-освітнього середовища, орієнтованого на побудову цілісної наукової картини. Однак її не можна “знайти” в підручнику або в лекціях викладача. Ї̈̈ можна тільки вибудувати на базі отриманих трансдисциплінарних знань, а це передбачає нову організацію навчального процесу.

На першому етапі підготовки фахівців (бакалавр / магістр) відповідно до вимог сьогодення компетентність $є$ однією зі складових загальної характеристики спеціальності. Головним стає результат навчання. Результати навчання можуть бути задані у вигляді опису того, що повинен знати, розуміти суб'єкт навчання по завершенню освітньої програми (дескриптори). Система дескрипторів є інваріантною, що полегшує підготовку та зіставлення різних освітніх систем. Як показав досвід, впровадження індивідуально-орієнтованого навчального процесу позитивно оцінюється студентами, оскільки це дає об’єктивну оцінку їх діяльності протягом кожного семестру, визначаючи їх рейтинг, що розширює їх права (вибору профілю, програми магістратури, зарубіжного стажування, отримання іменної стипендії тощо).

Навчання на другому етапі зовсім інше. ВН3 (навіть з багатими традиціями) не може навчити людину на все життя. Аналіз програм дисциплін

\section{Список літератури}

1. Палагин А. В. Проблемы трансдисциплинарности и роль информатики / А. В. Палагин // Кибернетика и системный анализ. - 2013. - № 5. - С. 3-13.

2. Палагін О. В. Міждисциплінарні наукові дослідження і оптимізація системно-інформаційної підтримки / О. В. Палагін, О. П. Кургаєв // Вісник НАН України. 2009. - № 3. - С. 14-15.

3. Палагин А. В. Онтологические методы и средства обработки предметных знаний / А. В. Палагин, С. Л. Крывый, Н. Г. Петренко. - Луганск : ВНУ им. В. Даля, 2012. - 323 c.

4. Прайд В. Феномен NBIC-конвергенции: реальности и ожидание / В. Прайд, Д. А. Медведев // Философские науки. - 2008. - № 1. - С. 97-117.

5. Nicolescu B. Transdisciplinarity - Theory and Practice (Ed.) / B. Nicolescu. - Hampton Press, Cresskill, NJ, USA, 2008. - 320 p.

6. Nicolescu B. Transdisciplinarity - past, present and future / B. Nicolescu // In Haverkott B. and Reijntjes C. (Eds). Moving Worldviews Conference Proceeding. Leusden, the Netherlands: ETC /Compas. - 2006. - P. 142-165.

7. Киященко Л. П. Феномен трансдисциплинарности опыт философского анализа / Л. П. Киященко // Santalka, Filosofia. - 2006. - T. 14, № 1. - C. 17-37. показує, що переважна їх кількість направлена на єдину цільову установку - передати знання у відповідній галузі знань. Але цього вкрай недостатньо.

Суспільство повинно заохочувати освіту протягом усього життя, тому так безперспективні сьогодні суперечки про те, скільки років повинен студент вчитися, які знання надавати у ВНЗ (фундаментальні або прикладні), а також дискусії стосовно фундаментальної ролі системи післядипломного навчання.

Суть самої трансдисциплінарності освіти базується на наявності суттєвої нелінійності науки, складності, самоорганізації, емерджентності інновацій, а її розвиток - на трендах, що грунтуються на холістичному баченні реальності.

Висновки: 1. Пропонується розділити навчання лікарів і провізорів у стратегії безперервного професійного розвитку в післядипломній медичній освіті на дві частини - базисну та додаткову (трансдицисплінарну, проблемно-орієнтовану) з заданим рівнем компетентності.

2. Трансдисциплінарність в освіті визначає вузлові предметні точки, через які об’єднуються природничі, соціальні та гуманітарні дисципліни, феноменологічні, описові підходи та підходи, що базуються на реальних, фундаментальних і прикладних законах, інженерних розрахунках і ад’ювантних дослідженнях.

8. Мокий В. С. Методологии трансдисциплинарности - 4 / В. С. Мокий. - Нальчик : Институт трансдисциплинарных технологий, 2011. - С. 5 - 59.

9. Прайд В. Феномен NBIC-конвергенции: реальности и ожидание / В. Прайд, Д. А. Медведев // Философские науки. - 2008. - № 1. - С. 97-117.

10. The European higher education and research landscape 2020. - Center for Higher Education Policy Studies, Universite ol Twente, 2005. - 219 p.

11. Ашин Г. Стратегия России в постиндустриальном мире и элитное образование / Г. Ашин // Власть. - 2008. № 1. - С. 8.

12. Judge A. Conference Paper. 1st World Congress of Transdisciplinarity / A. Judge // Union of International Associations. Available. - 1994. - Режим доступу : http:// www.uia.org/uiadocs/aadocnd4.htm.

13. Jantsch E. Vers l'interdisciplinarité et la transdisciplinarité dans l'enseignement et l'innovation / E. Jantsch // Léo Apostel et al. - 1986. - 106 p.

14. Трансдисциплинарность в философии и науке: подходы, проблемы, перспективы / под ред. В. Бажанова, Р. В. Шольца. - М. : Навигатор, 2015. - 564 с.

15. Гребенщикова Е. Г. Трансдисциплинарные основания инноваций в образовании / Е. Г. Гребенщикова, 
Л. П. Киященко // Філософія освіти. - 2013. - № 1 (12). - C. 210-222.

16. Jantsch E. Towards interdisciplinarity and transdisciplinarity in education and innovation / E. Jantsch // In L. Apostel G. Berger A. Briggs \& G. Michaud (Eds.), Interdisciplinarity: Problems of teaching and research in universities. - Nice : University of Nice, 1972. - P. 97-121.

17. Nicolescu B. Manifesto of Transdisciplinarity. Albany / B. Nicolescu. - NY : State University of New York Press, 2002. $-170 \mathrm{p}$.

18. Handbook of Transdisciplinary Research. A Proposition by the Swiss Academies of Arts and Sciences / G. Hirsch
Hadorn, H. Hoffmann-Riem, S. Biber-Klemm [et al.]. Heidelberg : Springer, 2008. - 506 p.

19. Krohn W. Interdisciplinary cases and disciplinary knowledge. The Oxford handbook of interdisciplinarity / W. Krohn. - New York : Oxford University Pr; 2010. P. 31-49.

20. Палагин А. В. К вопросу системно-онтологической интеграции знаний предметной области / А. В. Палагин, Н. Г. Петренко // Математичні машини і системи. - 2007. № 3, 4. - C. 63-75.

21. Schweber S. Complex Systems, Modelling and Simulation / S. Schweber, M. Wachter // Studies in History of Modern Physics. - 2000. - Vol. 31, № 4. - P. 585. 